\title{
Network governance in the heritage ecology
}

\author{
Richard A. Courtney ${ }^{1}$
}

(C) The Author(s) 2017. This article is an open access publication

\begin{abstract}
This article examines an AHRC 'Co-Design and Co-Production' project focussed on the decision-making processes within the 'heritage ecology'. The project involved three UK universities and a range of heritage institutions and community organisations. The project set out to empower community organisations through an emphasis upon deliberative democracy. Heritage is conceptualised as public value because it is used to define identity and belonging in civil society. Network governance theory is used to characterise the operational capabilities and the decision-making environment in the heritage ecology. The article argues that the public value of heritage is realised through network governance when 'human elements', such as emotional value are authentically and legitimately represented in deliberative processes.
\end{abstract}

Keywords Network governance $\cdot$ Heritage $\cdot$ Public value $\cdot$ Deliberative democracy $\cdot$ Co-production

\section{Introduction}

This article presents a reflective examination of an AHRC funded 'Co-Design and Co-Production' project focussed on the decision-making processes within the 'heritage ecology'. The project provides insights into the way in which network governance invokes the operational aspects of Moore's (1995) 'Strategic Triangle' in order to demonstrate the emergence of public value from heritage activity and interest, much of which describes the authorising environment. It also illustrates how the UK heritage ecology, long regarded as world leading is responding to

Richard A. Courtney

rac16@le.ac.uk

1 School of Business, University of Leicester, University Rd, Leicester LE1 7RH, UK 
global challenges to public finance and value (Scott 2013). The project is presented as a paradigmatic case study of network governance and involved three UK universities, a range of small community based organisations, two established UK museums, a major funder of UK based heritage programmes, and an organisation responsible for the custodianship of Scotland's archaeological and historic environment. The project set out to empower community organisations and 'leftfield' interests within the heritage sector with an emphasis upon deliberative democracy. This was innovative for a sector broadly conceived to be risk averse and exclusive in terms of its demographic make-up and representation (Hewison 1987). The project demonstrated the 'functioning' of the strategic triangle to create public value identified by Moore (1995), and re-iterated by Alford and O'Flynn (2008, 2011) within the heritage ecology.

The article explores the ways in which the wider 'heritage ecology' embodies the strategic triangle of public value as it features an authorising environment; operational capabilities, and a task environment. The invocation of the strategic triangle as a lens to identify the emergence of public value from the heritage ecology responds to Rhodes and Wanna's (2009) critique to overcome the dualism in public value theory, where it is both normative and empirical. Over recent years the ecology has devolved much of its traditional structures of authority and governance from centralised institutions to local and community organisations. This follows the established trend where government is superseded by governance in public policy (Nyholm and Haveri 2009). It is in this environment that community associations have inherited operational capabilities in the custodianship and promotion of heritage assets and interests; and have performed a leadership role in identifying the public value potential of local heritage so as to create a new authorising environment. The demonstrates that the operational capabilities of networked community governance (NCG) to create public value in regards heritage are empirically identifiable as opposed to being normative aims of wider strategy. Heritage is a vital social resource for individuals to express identity and belonging, but furthermore is a medium to mobilise deliberative democracy to enhance local decision-making. The article suggests that heritage is a solution to what Stoker (2006) suggests needs to be done to create 'engagement on their own terms': As heritage activity shows that people are active citizens keen to contribute to the decisions made over what is considered heritage and to whom it applies. In this way, it embodies normative aspirations associated with democratic values.

\section{How should heritage decisions be made?}

The project was funded as part of the AHRC's Co-Production research programme and was devised to experiment with the decision-making processes in the heritage ecology. The project included non-HEP partners from across the private and public sectors, and included several community associations based in York. The term 'heritage ecology' was used by one of the partners to describe the administrative, political, economic, and social context within which decisions about heritage were 
made. This definition will be elucidated upon further in the article. The project also included different examples of heritage decision-making contexts.

These contexts included, the Royal Commission for the Archaeological and Historic Monuments of Scotland's (RCAHMS) project entitled: 'From Source to Sea'. This was a public engagement exercise to identify the ways in which the public identified with aspects of the built and natural environment surrounding the Clydebank in Scotland. Another example was 'Experimenting at the Science Museum', this context used music synthesisers to generate a conversation about the ways in which the London Science Museum adds to its collections. A further context focussed upon the 'subaltern' social and cultural heritage of the City of York. Along with York's Civic Trust these associations have promoted a public understanding of heritage that transcends market and political logics, an ethic that was an aspiration of the project more generally. A final context was Bede's World in Jarrow, which is a community-led initiative that manages the Bede's World site and uses 'heritage' as a medium through which community engagement can be achieved (Bashforth et al. 2016).

The project team further represented the complexities of the heritage ecology through partnering with several institutions and organisations that have governance responsibilities in terms of representing heritage and delivering public funds for its promotion. These were, the Heritage Lottery Fund, and Leicester City Council; in addition, the National Co-ordinating Centre for Public Engagement supported the public engagement focus of the project. The project used 'complexity theory' as a frame of reference to describe the heritage ecology as a complex of decision-making entities, which include institutions, organisations, associations, communities, and individuals (Heritage Decisions 2015). This dynamic was captured by the project team as a system represented through different actors, agencies, rationalities, and practicalities. Through a series of workshops the research team mapped out a system of heritage decision-making that identified several problems or 'sticking points'. A long-standing issue in heritage studies is the hierarchical nature of management and custodianship, which has conventionally been regarded as paternalistic (Hewison 1987; Madgin 2009). In recent years, a large body of critical scholarship has emerged to challenge this orthodoxy in terms of the values it promotes (Madgin and Taylor 2015; Mason 2008; MacDonald 2009), the demographics it addresses (Courtney 2013), and the public accountability of decision-making processes (Schofield 2008). This has questioned the meaning, purpose, and use of heritage to arrive at a state of complexity where there is no singular conception or attachment to heritage.

The project explored how complexity itself can be better appreciated in the decision-making process in order to secure a more democratic approach. These decision-making processes are embedded in organisational and administrative contexts of public management and accountability, because they pertain to who or what is recognised publically as heritage. For this reason, this article refers to these decision-making contexts as the 'authorising environment' from which public value is created. Stoker's (2006) concept of network community governance (NCG) is used to illustrate the 'operational capabilities' that work with the authorising environment to create public value in the form of heritage. 


\section{Network governance}

Network governance is a concept that has found popularity in the public administration literature as both an explanative concept (Lewis 2011) and a prescriptive device to drive public management towards the creation of public value (Gains and Stoker 2009; Stoker 2006). Furthermore, it is used to explain a move away from centralised hierarchical authority and markets in the administration of public services (Bevir and Richards 2009). This move away from traditional modes of governance has led to the inclusion of a wider array of partners in service delivery, including business, not-for profit organisations, and communities (Dal Molin and Masella 2016). This has been seen to emerge from service delivery issues in water management (Behagel and Arts 2014), environmental protection (Robins et al. 2011), health services (Sheaff et al. 2014) and educational leadership (Hatcher 2014) amongst others. Consequently, network governance explains a changed relationship between the state and society, where institutions are not monolithic in their control over public assets and services, but have specific roles within a wider choreography of actors (Lewis 2011). This reality has itself been subject to criticism as it is seen to be a wider symptom of neo-liberal public management, where the state is 'hollowed-out' with risk and responsibility moved to non-state agencies and partners (Hatcher 2014; Skelcher et al. 2005). This move echoes the UK 2010-2015 Coalition Government's 'Big Society' agenda, where fiscal austerity is justified as democratic decentralisation (Dowling and Harvie 2014). This is true in the context of heritage management where many of the Quangos that were custodians of heritage, e.g. British Waterways, English Heritage etc. have been dissolved or transformed into trusts. At an organisational level, museum services have also had to change their management styles in respect of fiscal austerity (Coles 2008). Critics claim therefore that the move to networked forms of governance is the outcome of policy designed to limit the role of the state's fiscal responsibilities (Dowling and Harvie 2014). It is also argued that public value management overall could be considered an adjunct to NPM (Dahl and Soss 2014). However, many have argued that despite the policy emergent nature of network governance, the concept encourages participatory and deliberative democracy, as decision-making is potentially made more available to non-state actors (Behagel and Arts 2014; Sörensen and Torfing 2009; Stoker 2006).

It is this appeal to democracy that the concept finds its most plausible defence (Sörensen and Torfing 2009). Indeed, this is where Stoker (2006) identifies NGC to be different in substance from network governance per se. Stoker argues that the inclusion of community interests into governance networks in terms of decisionmaking is a key means through which a 'breath of life' is injected into local politics. This is because networks include people on the basis of their personal motivation, which is autonomous from rules or incentives traditionally used to drive service innovation and delivery. This develops Moore's (1995) notion of enterprise in public service delivery to maximise public value through network governance. This promotion of network governance is underwritten by an appeal to sociological concepts to define human characteristics rather than utilitarian concepts. Stoker 
(2006) argues that people are naturally cooperative and that network governance appeals to this nature. This is because networks are a reflection of how people organise themselves in quotidian ways (Mould et al. 2012). Consequently, networks offer the potential to a form of governance emblematic of how people live and communicate in society as opposed to top-down governance from institutions that embody instrumentalism (Klijn 2008). Davies (2012) argues that for networks to succeed they need to develop and sustain trust between actors, because it is trust in each others' intentions and actions that replaces command as the guiding instrument of governance. The distribution of trust and its reciprocity is also argued by Provan and Kenis (2007) to be vital to network effectiveness. These arguments are sociological in the sense that they refer to a social version of the individual and not a self-interested economic rational actor.

Wachhaus (2011) extends this defence of network governance through an emphasis upon the horizontal nature of networks. He argues that anarchism is a conceptual means to understand how networks can replace a 'language of hierarchies'. This is because anarchy favours bottom-up organic association over and above hierarchical command; and favours a flat ontology characterised by horizontal relationships (Marston et al. 2005). More importantly, anarchism represents organisation as dynamic rather than structured and in this way the selfinterested economic rational actor used in many governance theories is replaced with a cooperative vision of human behaviour, where humans are represented as 'social animals'. Wachhaus (2011) further argues that this cooperative nature means that goals are more effectively achieved than through individual effort. Interestingly, this feature of networks is also argued to benefit institutions in terms of their design (Shaw 2013). Capaldo (2014) argues that inter-organisational cooperation can lead to a higher yield in knowledge benefits due to the joint pursuance of strategic outcomes. In addition, Considine (2013) argues that an institutional use of networks can illustrate different ways of doing things that prevent institutional lockin and path dependency. Consequently, network governance can vitalise institutions in addition to providing democratic benefits through its sociological understanding of human co-operation.

As mentioned above, Stoker (2006) makes a distinction between network governance and network community governance. This means that networks can take different forms to achieve different ends, with NCG having a more democratic and participatory flavour (Gains and Stoker 2009). Therefore, there can be a tension between the beneficiaries of networks as if there is no meta-governance then institutional benefits can occur at the expense of democratic ones (Nyholm and Haveri 2009). Additionally, Provan and Kenis (2007) identify three modes of network governance that highlight alternative ways in which networks are led and function. These are participant-governed networks, lead-organisation networks, and network administrative organisation. They argue that the different ways these manage tensions is a predictor of their effectiveness rather than their immediate specificity to a governance issue or problem. Research into the governance networks of educational leaders by Hatcher (2014) has shown that authority-led networks have led to a depoliticisation of educational policy where networks can be exclusive and pursue a government agenda at the expense of community involvement. He 
argues that this is a neo-liberal restructuring of governance that is eroding notions of public good within educational policy. Sheaff et al. (2014) observe similar structural issues in the application of network governance approaches to health policy. However, they point to fewer democratic deficiencies in a top-down model of governance, but stress that performance targets and financial incentives set for networks do little to increase its effectiveness. This echoes the 'democracydelivery' tension identified by Skelcher et al. (2005), where public demands are often contradictory to the logic implied in service delivery. They argue that governance institutions are structured by managerial, consociational, and participatory discourses. They warn that the partnerships formed through networks operating in this way can erode accountability. This is because they are driven by an attempt to integrate vertical and horizontal forms of policy implementation rather than democratic needs.

These examples show that democratic participation, as a concept, is not fixed in the coordination of networks. Furthermore, the ability to replace vertical command and control with horizontal relationships does not necessarily relegate hierarchy (Nyholm and Haveri 2009). In fact, the example from Sheaff et al. (2014) shows that it can solidify top-down control, but that this may be beneficial in areas where a high degree of technical and scientific knowledge is required to identify policy objectives; or where the main actors are constituted as networks of institutions and large organisations - such as the UK heritage ecology. However, heritage is an issue that can be actively enjoyed and participated in with little formal training, skills, and knowledge - it therefore lends itself to the democratic ideals of NCG. This issue can be addressed through an exploration of how 'accountability' is represented in the network governance literature. The problem is that by their very nature networks include a wide array of actors in decision-making; accountability is then spread across the network as opposed to being focussed upon a particular institution or leadership role (Gains and Stoker 2009). So, while network governance can enhance democracy through inclusive decision-making it can make governance less transparent (Sörensen and Torfing 2009). This leads to a need for meta-governance in order to remain transparent in light of formal representative democracy. They argue that meta-governance anchors the network in inclusivity and access to scrutiny by those it affects.

Behagel and Arts (2014) argue that behind most discourses on governance are underlying normative assumptions of 'good governance'. They argue that governmental, instrumental, and deliberative discourses of governance structure decisionmaking in network governance. They claim that these rationalities bring a new dimension to accountability, as through the inclusion of the public the monitoring and reporting introduced through instrumental rationality is held up to public scrutiny. Behagel and Arts highlight that the deliberative discourse is enabled when a diversity of interests is represented. However, this is not always the case as conclusions from participatory exercises are often overturned at the political level and governmental rationality thus remains unchallenged. Robins et al. (2011) note that a structural signature registering the level of relational and structural embeddedness of the network enables a greater sense of accountability. This means the quality of the actors and their relationships are deemed to be important to 
the democratic effectiveness of network governance. Chapman and Lowndes (2014) also point to this conclusion when they highlight the role of 'authenticity' in regard participation in faith community networks. They argue that authenticity is a means to assess the legitimacy of non-state governance networks that fall outside the purview of 'representative democracy'. This is because authenticity of those involved generates trust on behalf of those governed by the network. These examples signal that inclusivity, trust, and openness are crucial tests for the accountability and legitimacy of network governance.

Critical to governance networks is then broad agreement over the purpose and aims of the network itself. Stoker (2006) argues that in order for network governance to operate effectively it must be coupled with public value management. This mode of public management is presented as a successor to new public management (O'Brien 2015). The difference is that the former is less dependent upon a 'consumer' identity ascribed to the users of public services and is more appreciative of the non-fungible aspects of public service, i.e. the public value of public libraries (So-Yoon and Seung-Hoon 2012), or public service broadcasting (Horner and Hutton 2011). This is because as noted earlier there is a sociological understanding of human nature as cooperative. Despite this, public value has been criticised as it is often vague as to whether it is normative or empirical. Rhodes and Wanna (2009) claim this is important as it has implications for its evaluation. Alford and O'Flynn $(2008,2011)$ argue that it can be both if the 'strategic triangle' is invoked as it can then become diagnostic; it can structure thinking; and it can analyse behaviour. This in turn allows for public value to be conceptualised as more than simply 'public goods' or 'public interest' as it is not just a constitutive element of the strategic triangle, but an outcome of its overall realisation.

As a result, public value management is argued to safeguard elements of public service from market forces (Hughes 2003). Public value, as argued by Stoker (2006) is created as public managers become more inclusive, enterprising and open to represent the values held within different public(s). Therefore, network governance and public value management are mutually re-enforcing organisational and political phenomenon-where the former is the medium through which the latter is created (Shaw 2013). Consequently, NGC can be conceptualised as the operational capabilities of heritage based activity in keeping with Moore's (1995) strategic triangle.

By invoking the strategic triangle, heritage can be regarded as a paradigmatic case study of network governance and public value (Flyvbjerg 2006). This is because heritage is a focal point around which individuals and communities structure and represent identity in their own terms. However, the ability to use heritage is often dependent upon formal or institutional recognition for funding or legitimation. The public status of heritage is exemplified through an ecology that consists of public, private, not-for-profit, and community interests. Furthermore, heritage is dynamic, fluid, and heterogeneous - the heritage ecology is a reflection of this complexity-this means that democracy is vital if decision-making is deemed to be effective, legitimate, and accountable. The heritage ecology is a living example of how networked governance naturally occurs in spaces vacated by 
formerly authoritative institutions and government; and in this way, embodies its operating environment.

\section{The 'heritage ecology': a third way between policy and the market}

The project problematized decision-making in heritage because heritage is a source of non-fungible human value, a human right, and is inherent to identity, which has been conventionally managed by political and economic forces (Hewison 1987; Scott 2013). It is therefore intrinsic to democracy as a public value and given its complex character in terms of meanings, associations, and attachments, lends itself to be considered crucial to deliberative or what Dryzek (1995) refers to as 'discursive democracy'. This is where democracy is enacted outside the symbolic institutions of elections as a procedure to ensure inclusivity in decision-making processes. However, heritage has become a heterodox platform upon which people structure identity and belonging in different and in conflicting ways (MacDonald 2009; Scott 2013). This has led to a 'post-modern' condition where it is no longer viable to structure heritage discourses vertically and without reference to multiple communities of interest. Smith (2006) argues that heritage management is organised along the principle of 'Authorised Heritage Discourse'. She argues that conventionally speaking, museums and other heritage management organisations present an image of heritage that speaks to national stories, but which obscures alternative accounts of what the histories are behind heritage discourse, alternative accounts of what can constitute heritage, and what and who can use heritage. These points were critical in the project, because we represented heritage as landscape and natural environment, cultural history, the built environment, craft legacies, community history, niche interests, and alternative and radical histories. Therefore, heritage is not a thing or one narrative, but a dynamic system where authentication and legitimation are often obscure, difficult to comprehend for people outside conventional heritage organisations, and inhibited by bureaucracy.

Heritage is therefore an important issue in public management, because firstly it pertains to the aspects of community life that structure identity and secondly because it relates to how its tangible aspects are funded and managed-namely its governance. When the project first met there was a cynicism towards heritage governance as many in the project felt that the authoritative nature of the major sponsors and institutions was a principle means through which exclusion occurred. This was experienced by the Bede's World management team who had become the custodians of the site through using a community-based cooperative style of management. This meant that everyone who used the site and its resources made decisions collectively. Indeed, they were resistant to the idea of becoming 'institutionalised' so as to avoid becoming overly bureaucratic and driven by the principles of new public management. The frustration for the Bede's World team was that heritage, as conventionally understood was managed through targets and financial incentives that quantify value in terms of footfall. For the Bede's World team public value was identified as 'footprint' - this was a term they used to identify the social value they played in the surrounding community. Despite the fact that 
they could justify their mission through metrics associated with footfall and enterprise they felt that an overly bureaucratic form of management was a straightjacket upon their wider social aims.

Other members of the project team developed a strand of action research to actively explore how more people could be involved in decision making. This was particularly the case for the York: Living with History project, which included York's Alternative History, and the York Past and Present facebook group. Together they explored how public debate about Stonebow House-a brutalist building in York referred to as 'York's most hated building' were not recognised by local authorities and only sub-consciously identified by local people (Graham 2015). York's Alternative History had devoted themselves to the identification of sites missing or overlooked in York's history, notably its connection to LGTB histories but, like York Past and Present, they lacked critical social capital to build the networks and legitimacy to be taken seriously by local authorities (Brigham et al. 2016). Heritage was therefore a public value that enabled them to engage with bureaucratic decision-making by building networks across institutional boundaries and between professionals and activists.

This included a workshop with the Heritage Lottery Fund (HLF), where the project team presented a series of provocations that identified issues they had with recognition and democratic decision-making. As the Heritage Lottery Fund are sanguine to these issues the workshop proved a useful tool of knowledge exchange, where the project team could learn more about policy and its development and the HLF could learn more about the identities of those willing to be included in decision-making processes - this was dubbed by one project member as a "coalition of the willing'. These conversations within the project and with outside organisations and institutions signalled a desire to create a 'flat ontology' for the heritage ecology - this is where decision-making is distributed horizontally, much like the anarchic mode of network governance promoted by Wachhaus (2011). The problem existed on the basis that due to wider organisational and environmental changes a space had opened up where heritage has become populated with a diversity of actors with different levels of social capital and different knowledge bases. The project was a key moment in these changes as it created a dialogue over how to coordinate this ecology in the interests of authentic governance that registered the reality and desirability of a flatter ontology.

\subsection{Heritage ecology and emotional value}

The recourse to the concept of ecology is an attempt to safeguard heritage from over-determination and managerialism by the market and polity. This is in order to incorporate intrinsic associations with heritage without diluting their value through market logic or political instrumentality. Holden (2015) expresses this similar assessment of the cultural sector in general when he discusses cultural value more broadly. Holden argues that cultural value is created and experienced across an ecology that includes a range of actors from the public, private, and third sectors, to DIY enthusiasts - these interests cross-cut values of intrinsic and instrumental rationalities. In this way, the term ecology is used more expressly to incorporate 
Hewison's (1987) critique of the commercialism and mediocrity of what he dubbed the 'heritage industry'. In his critique, Hewison claims that heritage was a top-down idea to appeal to middle class nostalgia. This nostalgia had become a sanitised and commercialised form of cultural appreciation, which distracts people from critical culture and thus denies them the opportunity to hold their own associations to heritage and history. In critical heritage studies, the subject is described as an opportunity for dialogue over what constitutes heritage and to whom it addresses (Hall 2008). Heritage is therefore a fluid social process not a monolithic and packaged phenomenon for passive consumption by the masses. An ecological approach encapsulates this socially reproductive nature and is premised around people's emotional attachments and values (Madgin 2009).

These emotional values were captured many times throughout the project. These included an event in York where participants were invited to design their own blue plaques in a similar vein to those sponsored by English Heritage. Similarly, at the London Science Museum the Head of Research \& Public History sought out networks of synthesiser enthusiasts (of which there is a burgeoning on-line community, see synthtopia.com) to advocate the inclusion into their collection of many memorable synthesisers central to the development of contemporary music. This was an interesting example to explore emotional attachment, because it was the flair and enthusiasm of what were referred to as 'synth-geeks' that created the authenticity behind the promotion of unique and under-represented synthesisers in music history. This was seen as a contrast to the often-instrumental nature of museum collections, where value is identified through expert knowledge contained within the curatorial community or an instrumental strategic vision. These values were epitomised by the argument that instead of the synthesisers existing in the collection for preservation they should be displayed for use-as it is their sound that signals heritage and emotional value rather than their material appeal. These instances stood as 'challenges' and 'experiments' with decision-making, but they are significant in this context because they utilised networks that went beyond institutional boundaries to identify new sites or objects bestowed with hidden emotional value and appeal. It was the very process of institutions opening up to this reality that allowed for these values to become publically identified and advocated-this was especially the case as the London Science Museum agreed to the inclusion of a Theremin in their collection on the basis of the experiment.

\subsection{What is 'authentic' in the heritage ecology?}

Debates surrounding heritage management and cultural management more generally have been structured by a dichotomy between intrinsic and instrumental values (Gibson 2008). It is emergent from this debate that the project attempted to encapsulate the intrinsic values of heritage from a multitude of perspectivesintrinsic values that were often represented as emotional attachments. Amongst the project members was a desire to conserve a sense of the non-instrumental in the promotion and enjoyment of heritage activities. This was rendered in the project as a 'heritage ethic' that spoke to the idea that history is psychologically, morally, and socially transformative. This was spoken of by a radical historian on the project as 
an emancipatory ideal and by the Head of Research \& Public History at the London Science Museum as a 'duty to the people of the past' and was about posterity. The project identified a number of instances where different public(s) could identify potential public value based upon their own emotional values, which they experienced as authentic next to a 'corporate', sterile, and overly managerial conception of heritage. It is this appeal to 'authenticity' that marks heritage out as an intrinsically different issue from other public issues covered in the network governance literature. This is because heritage is fundamental to democratic selfrealisation and is a legitimately contested concept. Unlike other public problems, the issues inherent in heritage decision-making contexts are not about finding one solution or confirming a universal representation, rather they are focussed on allowing for contestation to occur. The authentic credentials of those involved are emergent from the ways in which their emotional attachments are embedded within wider networks. In so doing, authenticity is a concept enmeshed with a diversity of emotional associations.

This is not a new phenomenon and heritage organisations, institutions, and funders have for a long time responded to publicly identified emotional attachments. This is through the inclusion of public history, intangible heritage, and appeals to diversify engagement with heritage in the mission statements of museums, trusts, and funding bodies (Courtney 2013). This has extended the franchise of heritage beyond the classic 'white middle class' audiences formerly addressed by the Heritage Industry (Hewison 1987). This has been a key institutional transformation that has enabled networks to prosper and for knowledge exchange to occur. Indeed, the listing process used by English Heritage is enacted through civic societies and individuals that seek out sites of historical value and then make the case to English Heritage as to their conservation and preservation status. The HLF are also founded on a tradition of community involvement in the identification and conservation of intangible and tangible heritage(s). Their 'All our Stories' grant programme served to make this available for a wide range of community interests, which included: The Stoke Pottery Tile trail, a representative of which worked on the project. Consequently, the project was a snapshot of this process in action, because the partners were brought together through their commitment to developing engagement and inclusion at a deeper democratic level.

However, the project identified a range of contexts in which this can occur and it was not exclusive to community participation. One of the academic researchers alongside Leicester City's Conservation Officer traced the decision-making process of the redevelopment of College Court in Leicester. They illustrated how emotional attachment is largely excluded in the planning process on the assumption that decisions are made rationally and in regard technical expert knowledge and conventional urban planning history. They identified that the emotional attachment of architects, developers, and other interested parties still remained, but was sequestrated by the objective and procedural language used in the planning process. They discovered that the building's significance was generated through the course of interactions between all those involved. This meant that its significance was a result of knowledge sharing between networks of divergent interests-central to these observations was that the 'knowledge' shared was often emotional and not 
solely instrumental. This aspect of the project signified that inclusivity is not a concept uniquely relative to identity, but also about legitimate discourses on useful knowledge.

In the above example, authenticity was something that emerged from knowledge exchange rather than advocacy on the part of non-institutional community interests. Authenticity was registered by the project as the 'human' element in decisionmaking, which existed alongside not in opposition to rationality and expert knowledge. Authenticity was sign-posted through emotional attachments that took a myriad of different expressions; but crucially was based upon involvement in decision-making to include the greatest number of voices who are permitted to use emotional value as a legitimate form of knowledge. This was a central idea for RCAHMS' strategy to conserve the Clydebank in Lanarkshire. Their strategy was to use a pop-up shop to create an opportunity for the public to map their associations with the surrounding landscape. This enabled them to capture the significance of historical and natural features held by different publics and they used a range of creative activities to bring this to life. These examples show that authenticity registered through emotional value is a central knowledge upon which heritagedecisions are made and subsequently represents the 'breath of life' argued by Stoker (2006) to be lacking in network governance. The examples reveal that emotional attachment and authenticity are not solely attributes of the public, but can be taped into when institutions and organisations commit themselves to a deeper level of public engagement in how heritage is used.

\subsection{What are the 'uses' of heritage?}

Despite its appeal to democratic decision-making, heritage is not just an end in itself as it also has a use-function. This is as a medium to achieve other aims, be they democratic, commercial, or managerial. In this regard, it is a central source of 'cultural capital' that has the potential to reap value in other social, political, and economic domains (Belfiore and Bennett 2008). Indeed, it is this potential that is followed by cultural policy for instrumental reasons (Belfiore 2002). Many in cultural policy studies regard the instrumentalism attached to culture and by association heritage to have under-appreciated the intrinsic values that people have for the cultural environment (Holden 2006). It is argued that heritage is used to achieve social, political, or economic value at the expense of these values. However, heritage sui generis and its use-value are often difficult to de-couple. This is because arguments that advocate the intrinsic value of heritage normally have external reference points, such as its impact on identity, its transformative capacities, and its organising potential. These were factors registered across the partners in the project, but what signalled their difference to policy orientated notions of instrumentality were that they were founded upon ideas of ownership in addition to deliberative approaches to decision-making. For MadLab in Manchester, their modus operandi was science, technology, and digital innovation rather than heritage; despite this, heritage became a useful tool for them to organise local people's creative energies towards these goals. As a not-for-profit grassroots organisation, heritage could be 
used as a medium to advocate community ownership of the meanings, associations, and values of their local built and social environment.

This power of heritage to captivate, engage, and organise people through ownership of decision-making is further exemplified by the Bede's World management ethos. This example illustrates the power of heritage as a catalyst to develop social services for isolated and excluded members of the local community. Its constituent users manage Bede's World and the uses of the site are many and varied. They play host to a local college through receiving some of their low attending students who are in precarious positions and are at risk of falling into crime. Bede's World has seen the attendance of these young people rise as they are given opportunities to work on the site in a range of different capacities, including catering, curating, and skilled craft work such as stonemasonry. Another example is their 'men in sheds' activities, where older men, many of whom are widowers have the opportunity to use the wood shop on their site. The men are given instruction in carpentry and they're allowed to make stuff of their own choice in addition to designing and producing items for the museum such as the on-site signage. The museum is not solely a museum of 'Bede's world', but a social space inspired by Bede in respect of his commitment to arts and crafts. The museum shows how a cooperative style of management gains social legitimacy through the collective ownership of decision-making. This is extended to include a wider footprint in the community by providing opportunities for self-development, self-realisation, and social inclusion. This is because it represents a strategic, moreover than instrumental use of heritage that is on people's own terms and not an outcome of policy and strategy drawn up by distant and faceless institutions. Indeed, it is through collective decision-making that the authenticity of Bede's World shines through; it is a social space for itself, rather than in itself, and as such encourages a collective ownership of the uses of heritage.

As heritage reflects peoples' senses of authenticity, ownership, and emotional and cultural values it embodies public value. This is because, these often emotionally charged issues are experienced as being exposed to market forces and a reductive approach to public service by local and national government. The project revealed that a network governance approach to heritage that is inclusive and that registers a diversity of emotional attachments could create feelings of authenticity and ownership. NCG can be seen as a medium through which the human element of heritage decision-making can be safeguarded from managerialism and market forces. Consequently, it creates a public value that is otherwise extinguished or un-appreciated. This value is epitomised in a story told to myself by one of the 'men in sheds' at Bede's World after I had asked the director what he thought most identified the site's public value. The man described being stuck down a dark hole shouting out for help. After a few people wandered by and ignored his calls for help another person jumped down the hole. 'Now you're stuck down here too' responded the first man, to which the second man replied 'Yes, but I know how it feels'. This was how one man described how he felt Bede's World had touched his life and that without it he would be stuck in the abyss grieving for his lost wife. This follows Moore's (1995) conception of public value, where value is created from the strategic triangle rather than simply providing value for taxpayers' money. In this 
way, public value is not created simply from the modus operandi of the institution, i.e. to manage heritage assets, but to do something with them that touches peoples' lives. The onus is then on everybody involved, communities and institutions alike to adopt more strategic network forms of governance that achieve these ends.

\section{Conclusions}

Heritage is a hotbed of public value precisely because it speaks to many different publics through a multitude of different media, such as synthesisers, buildings, the historic environment, or historical figures. As an authorising environment, heritage demonstrates that shortcomings of public value theory identified by Rhodes and Wanna (2009) can be circumvented through inclusivity beyond the traditional public manager roles. Additionally, it can be used to have an impact on other social, economic, and cultural domains. It is in this way fluid, not monolithic, and lends itself to a conception of a flat ontology rather than a vertical hierarchy (Marston et al. 2005; Shaw 2013). Therefore, it is vital to explore the ways in which heritage is governed as a network of diverse interests. It is argued in this paper that NCG is a viable means for heritage to be governed, because it demonstrates its operational capabilities and creates a platform to extend inclusion, participation, and diversity. NGC therefore characterises the operational capabilities of heritage as an ecology of interested parties that when strategically choreographed together create public value. The project team was a snapshot of this ecology that revealed the difficulties experienced by people outside the mainstream of heritage discourse to be recognised as authentic in their heritage pursuits. The overall benefit of conceiving heritage as an ecology governed through networks is that it provides an opportunity for people to safeguard heritage from market forces and too much bureaucracy. This is because it prizes heterodoxy over orthodoxy and enables people to actively engage in critical culture rather than overly managed and sterile culture.

Central to the heterodoxy that network governance can aid to thrive is an expansion of what can be considered legitimate knowledge in decision-making processes. Knowledge in the form of acceptance and understanding of diverse emotional attachments and values can be used to scaffold the authenticity of actors within the network. Much like Chapman and Lowndes (2014) argue in terms of faith communities, authenticity is a marker of the network's legitimacy and one component of the strategic triangle. In this way, it serves as a central means to overcome the democratic deficits identified with network governance and its relationship to formal representative democracy. Authenticity is a concept close to people's hearts, because it signifies a human element within decision-making scenarios that is obscured by bureaucratic management. This is especially the case with culture and heritage as these issues naturally spark emotion and therefore the ways in which they are managed needs to build upon this spark for people to be inspired to become active. In this way, network governance can as Stoker (2006) argues become the means to allow this 'breath of life' back into politics and decision-making. This means that the authorising environment within which heritage decisions are made demonstrates a more democratic realisation of the 
strategic triangle, which it is argued here circumvents criticisms by Rhodes and Wanna (2009) that public value theory is both confused over its role as an empirical reality and normative prescription and that it forces public managers to act in often un-democratic and un-legislated ways.

As an invocation of the operating aspects of the strategic triangle, NGC creates the space for the public to be appreciated as the creators of public value of which institutions recognise and acknowledge as part of their transformation in an age characterised by governance not government. Bede's World in Jarrow exemplifies this ethos as cooperative ownership of heritage and its meanings remain central to their mission. Through the manifestation of authenticity based upon emotional value and attachments the Bede's World team managed to use heritage in a strategic fashion to illustrate that heritage can be used in socially productive ways that resisted instrumentalism and bureaucracy. This was an objective that also existed in other project members, such as MadLab in Manchester and the York: Past and Present Group, where heritage was used as a vital source of cultural capital for citizens to become active in the management of their built environment. These concepts need to be central components of the learning experiences emergent from networks; inclusivity and diversity are litmus tests as to the democratic effectiveness of network governance.

Open Access This article is distributed under the terms of the Creative Commons Attribution 4.0 International License (http://creativecommons.org/licenses/by/4.0/), which permits unrestricted use, distribution, and reproduction in any medium, provided you give appropriate credit to the original author(s) and the source, provide a link to the Creative Commons license, and indicate if changes were made.

\section{References}

Alford, J., \& O’Flynn, J. (2008). Public value: A stocktake of a concept. https://ssrn.com/abstract= 1927671 or https://dx.doi.org/10.2139/ssrn.1927671.

Alford, J., \& O'Flynn, J. (2011). Making sense of public value: Concepts, critiques, and emergent meanings. International Journal of Public Administration, 32, 171-191.

Bashforth, M., Benson, M., Boon, T., Brigham, L., Brigham, R., Brookfield, K., et al. (2016). Socialising heritage/socialising legacy. In K. Facer \& K. Pahl (Eds.), Connected communities legacies. Bristol: Policy Press.

Behagel, J. H., \& Arts, B. (2014). Democratic governance and political rationalities in the implementation of the water framework directive in the Netherlands. Public Administration, 92(2), 291-306.

Belfiore, E. (2002). Art as a means of alleviating social exclusion: Does it really work? A critique of instrumental cultural policies and social impact studies in the UK. International Journal of Cultural Policy, 8(1), 91-106.

Belfiore, E., \& Bennett, O. (2008). The social impact of the arts: An intellectual history. London: Palgrave.

Bevir, M., \& Richards, D. (2009). Decanting policy networks: A theoretical agenda. Public Administration, 87(1), 3-14.

Brigham, L., Brigham, R., Brown, P., \& Graham, H. (2016). Living with history in York: Increasing participation from where you are. In G. Chitty (Ed.), Heritage, conservation and communities. Farnham: Ashgate.

Capaldo, A. (2014). Network governance: A cross-level study of social mechanisms, knowledge benefits, and strategic outcomes in joint-design alliances. Industrial Marketing Management, 43, 685-703.

Chapman, R., \& Lowndes, V. (2014). Searching for authenticity? Understanding representation in network governance: The case of faith engagement. Public Administration, 92(2), 274-290. 
Coles, A. (2008). Instrumental death of a reductionist. Cultural Trends, 17(4), 329-334.

Considine, M. (2013). Governance networks and the question of transformation. Public Administration, 91(2), 438-447.

Courtney, R. (2013). The contentedness of a content-less Englishness. Context-A Journal of the Institute of Historic Building Conservation, 132, 26-27.

Dahl, A., \& Soss, J. (2014). Neo-liberalism for the common good? Public value governance and the downsizing of democracy. Public Administration Review, 74(4), 496-504.

Dal Molin, M., \& Masella, C. (2016). Networks in policy, management, and governance: A comparative literature review to stimulate future research avenues. Journal of Management and Governance, 20, $823-849$.

Davies, J. (2012). Network governance theory: A Gramscian critique. Environment and Planning A, 44, 2687-2704.

Dowling, E., \& Harvie, D. (2014). Harnessing the social: State, crisis and (big) society. Sociology, 48(5), $869-886$.

Dryzek, J. (1995). Discursive democracy: Politics, policy, and political science. Cambridge: Cambridge University Press.

Flyvbjerg, B. (2006). Five misunderstandings about case-study research. Qualitative Inquiry, 12(2), 219-245.

Gains, F., \& Stoker, G. (2009). Delivering 'public value': Implications for accountability and legitimacy. Parliamentary Affairs, 62(3), 438-455.

Gibson, L. (2008). In defence of instrumental value. Cultural Trends, 17(4), 247-257.

Graham, H. (2015). Legitimate expertise: How decisions are made. Context-A Journal of the Institute of Historic Building Conservation, 142, 15-17.

Hall, S. (2008). Whose heritage? Un-settling 'the heritage', re-imagining the post-nation. In G. Fairclough, R. Harrison, J. H. Jameson, \& J. Schofield (Eds.), The heritage reader. London: Routledge.

Hatcher, R. (2014). Local authorities and the school system: The new authority-wide partnerships. Educational Management Administration and Leadership, 32(3), 355-371.

Heritage Decisions. (2015). How should heritage decisions be made?: Increasing participation from where you are. Available: http://heritagedecisions.leeds.ac.uk/.

Hewison, R. (1987). The heritage industry: Britain in a climate of decline. London: Methuen.

Holden, J. (2006). Cultural value and the crisis of legitimacy: Why culture needs a democratic mandate. Demos Report.

Holden, J. (2015). The ecology of culture. A Report Commissioned by the Arts and Humanities Research Council's Cultural Value Project.

Horner, L., \& Hutton, W. (2011). Public value, deliberative democracy and the role of public managers. In J. Benington \& M. H. Moore (Eds.), Public value: Theory \& practice. Palgrave: Basingstoke.

Hughes, O. E. (2003). Public management and administration: An introduction. London: Palgrave.

Klijn, E. H. (2008). Governance and governance networks in Europe: An assessment of 10 years of research on the theme. Public Management Review, 10(4), 505-525.

Lewis, J. M. (2011). The future of network governance research: Strength in diversity and synthesis. Public Administration, 89(4), 1221-1234.

MacDonald, S. (2009). Difficult heritage. London: Routledge.

Madgin, R. (2009). Heritage, culture and conservation: Managing the urban renaissance. Saarbrucken: VDM Verlag.

Madgin, R., \& Taylor, M. (2015). Who do heritage values belong to? Context-A Journal of the Institute of Historic Building Conservation, 142, 12-14.

Marston, S., Jones, J. III, \& Woodward, K. (2005). Human geography without scale. Transactions of the Institute of British Geographers, 30, 416-432.

Mason, R. (2008). Assessing values in conservation planning: Methodological issues and choices. In G. Fairclough, R. Harrison, J. H. Jameson, \& J. Schofield (Eds.), The heritage reader. London: Routledge.

Moore, M. (1995). Creating public value: Strategic management in government. Cambridge: Harvard University Press.

Mould, O., Vorley, T., \& Courtney, R. A. (2012). My network is not working: Conceptualising the latent and dysfunctional dimensions of the network paradigm. Economic Geography, 88(1), 77-96.

Nyholm, I., \& Haveri, A. (2009). Between government and governance-local solutions for reconciling representative government and network governance. Local Government Studies, 35(1), 109-124. 
O'Brien, D. (2015). Cultural value, measurement and policy making. Arts and Humanities in Higher Education, 14(1), 79-94.

Provan, K. G., \& Kenis, P. (2007). Modes of network governance: Structure, management, and effectiveness. Journal of Public Administration Research and Theory, 18, 229-252.

Rhodes, R. A. W., \& Wanna, J. (2009). Bringing the politics back in: Public value in Westminster parliamentary government. Public Administration, 87(2), 161-183.

Robins, G., Bates, L., \& Pattison, P. (2011). Network governance and environmental management: Conflict and cooperation. Public Administration, 89(4), 1293-1313.

Schofield, J. (2008). Heritage management, theory and practice. In G. Fairclough, R. Harrison, J. H. Jameson, \& J. Schofield (Eds.), The heritage reader. London: Routledge.

Scott, C. (Ed.). (2013). Museums and public value: Creating sustainable futures. Ashgate: Farnham.

Shaw, R. (2013). Another size fits all? Public value management and challenges for institutional design. Public Management Review, 15(4), 477-500.

Sheaff, R., Windle, K., Wistow, G., Ashby, S., Beech, R., Dickinson, A., et al. (2014). Reducing emergency bed-days for older people? Network governance lessons from improving the future for older people' programme. Social Science and Medicine, 106, 59-66.

Skelcher, C., Mathur, N., \& Smith, M. (2005). The public governance of collaborative spaces: Discourse, design and democracy. Public Administration, 83(3), 573-596.

Smith, L. (2006). Uses of heritage. London: Routledge.

Sörensen, E., \& Torfing, J. (2009). Making governance networks effective and democratic through metagovernance. Public Administration, 87(2), 234-258.

So-Yoon, K., \& Seung-Hoon, Y. (2012). The public value of a national library: Results of a contingent valuation survey. Journal of Librarianship and Information Science, 44(4), 263-271.

Stoker, G. (2006). Public value management: A new narrative for networked governance? American Review of Public Administration, 36(1), 41-57.

Wachhaus, A. (2011). Anarchy as model for network governance. Public Administration Review, 72(1), 33-42.

Richard A. Courtney is interested in the management of cultural resources and activities. Particularly in regards public value theory and entrepreneurship. He has published on issues regardings cultural management of Englishness. 